\title{
Principal’s Strategies for Leading ICT Integration: The Malaysian Perspective
}

\author{
Sathiamoorthy Kannan, Sailesh Sharma, Zuraidah Abdullah \\ Institute of Educational Leadership, University of Malaya, Kuala Lumpur, Malaysia \\ Email: drsathia@um.edu.my, sharmuco@um.edu.my,zuraidahab@um.edu.my
}

Received 2012

\begin{abstract}
This study is the first of its kind in the nation to examine the strategies used by principals in leading the ICT integration among their teachers. It also attempted to study the extent to which these strategies are being used, the top ten practices in each of these strategies, and whether there exist demographic differences in the use of the strategies. A survey method, using the Principal Leading ICT Integration Questionnaire (PLICTQ), was employed to capture all the relevant information. A sample of 106 princi-pals from two neighbouring states in Malaysia participated in this study. The findings indicate that prin-cipals use all the three strategies (modeling, promoting and creating opportunities) but at varying degrees of strengths. The modeling is found to be the strategy with the highest degree of strength followed by creating opportunities, and finally promoting strategy. As for the demographic variables, the find-ings indicate significant differences for the academic qualifications (first degree and post graduate) and the training (yes and no). However, gender differences were not significant in the analysis. This study suggests that the higher the academic qualification, the better the principals in understanding and show-ing good technology leadership. Those who said that they had some training indicated a higher mean in all three strategies. One important suggestion that can be drawn from here is that if these principals are provided with the appropriate professional development in technology leadership, then they can really excel to even higher levels in exhibiting ICT leadership for their teachers.
\end{abstract}

Keywords: Principals’ Strategies; ICT Integration; Leading; Modeling; Creating Opportunity; Promoting

\section{Introduction}

Many researches on technology best practices for teaching and learning indicate that principals are a key to sustained technology integration in any school building. And that principals express a strong interest in developing instructional leadership skills for the integration of technology into teaching and learning. In her research on principals' leadership and ICT integration, Yee (2000) found that the schools that integrated ICT in the most constructive way were those where the principals shared an unwavering vision that ICT had the potential to improve student learning. These principals also portrayed passionate commitment to providing professional development to enhance their teachers’ ICT skills. Schiller (2000), talks about the key roles that the principals need to play such as highlighting supporting technology, and facilitating change and intervention strategies in the teaching and learning process. Schools with the highest technology use shared the characteristic of a strong, enthusiastic principals supporting their convictions about technology by allocating resources and scheduling professional development in ICT for their teachers (Stegall, 1998). Effective principals need to be actively involved with technology, including modeling the technology use and helping to implement ongoing curriculum-integrated technology staff development. While discussing the role of the administrator in technology integration, Ritchie (1996) states that principals must mobilize their teachers to create a technology culture. Indeed, Hope and Stakenas (1999) suggested three primary roles for the principal as technology leaders for better ICT integration among their teachers: role model, instructional leader, and visionary.

In order for successful implementation of ICT applications among teachers, Macneil and Delafield (1998) commented that principals need to use their existing resources wisely and creatively. They ought to "think outside the box' and they must think in a fluid environment. In addition, they need to establish a vision for the school, a context for technology in the school to empower teachers and help students become more technology literate (Brockmeier, Sermon, \& Hope, 2005). In a study of the correlation between teachers' perceptions of principal's technology leadership and the integration of educational technology, Rogers (2000) found that teachers who had positive perceptions about the principal's role in supporting the integration of technology were more likely to integrate technology themselves.

\section{The Setting}

Malaysia is a fast developing nation and aspires to be a developed nation by 2020. It is actually investing a lot of money in developing the infra structure as well as in building the teachers' skills in ICT because it believes that with ICT as an enabler in the classroom instruction, it can enhance the student learning and finally achieve its ultimate goal of being a developed nation by 2020 . However, many of the country's principals are not fully aware of their role as technology leaders. In some of the studies that were conducted in the nation, it could be seen that they were practicing only some of the technology leadership skills. They are probably doing it quite unknowingly. Rossafri and Balakrishnan (2007), noted that most of these school leaders are at the lower end in terms of the knowledge 
and skills related to ICT applications and are usually quite uncomfortable when it comes to technology leadership. This in turn makes them least responsible as technology leaders. These school leaders need to be aware of their roles as technology leaders. In addition by being technology leaders, the school principals must ensure that teachers receive adequate professional development, technical support, and resources to realize the technological benefits for their use in the classrooms.

According to Wilmore and Betz (2000) to date there have been limited studies on the role of the principal and the implementation of ICT in schools. Likewise, there are not many studies that have been recorded on school principal's technology leadership in the local literature. A study by Kamala (2008) reported that the principals of one district in the state of Negeri Sembilan, Malaysia were performing their role as technology leaders at least at the average level. However, two more studies have been brought in here for further discussion. In the study by Nordin \& Razak (2010) entitled "A quantitative analysis of Malaysian technology leadership" that appeared in the Journal of Management Science and Engineering in April 2010, the researchers found that all 63 administrators scored AVERAGE on all the variables of Leadership and Vision, Learning and Teaching, and Productivity and Professional Practice. Only three of the six dimensions for the administrators that were stipulated in the ISTE (2002) were tested in this study. There were no significant differences between male and female school administrators in all the variables of Leadership and Vision, Learning and Teaching, and Productivity and Professional Practice.

The other is a comparative study by Sathiamoorthy, Leong and Jamil (2011) entitled "Principal Technology Leadership and Teachers' ICT Applications in two different school settings in Malaysia. This paper was submitted for presentation at the International Conference On "Aplication of ICT in economy and education“ (icaictee 2011), December 2 - 3, 2011, UNWE, Sofia, Bulgaria. In this study the principal technology leadership and teachers' ICT applications were made the main variables in two different settings, one a normal day school and another a smart school. All six dimensions of productivity and professionalism dimension; support, management, and operations; assessment and evaluation; leadership and vision; learning and teaching; and social, legal, and ethical issues were tested in this study. The smart school principal ranked ABOVE AVERAGE in the productivity and professionalism dimension, while keeping the other five dimensions of support, management, and operations; assessment and evaluation; leadership and vision; learning and teaching; and social, legal, and ethical issues at an average rank. In contrary, the principal in the normal day school, ranked at an ABOVE AVERAGE level in the social, legal and ethical issues dimension while the other dimensions were all ranked average only. Why would there exist such a different need or perceived need among these principals? In their study on aspiring principals, Traci and Chan (2010) found that some aspiring administrators do select the dimensions of support, maintenance, and operations and assessment and evaluation as more important and demanding for special emphasis than the others.

There were no other local studies that went beyond this technology leadership levels. Knowing that the Malaysian principals are already exercising some technology leadership skills to a certain extent, this piece of research went beyond that by looking at the principals' strategies in leading the teachers' ICT integration.

\section{The Research Questions}

Specifically this study focused on answering the following four research questions.

Q1: What are the strategies principals use for leading the ICT integration among their teachers?

Q2: To what extent these strategies are being used to lead the ICT integration among their teachers?

Q3: What are the top 10 practices in each of these strategies?

Q4: Are there significant demographic differences in the principals' strategies for leading the ICT integration?

\section{Methodology}

As for the theoretical framework for the study, the researcher gives all credits to the findings of the researcher, Kozloski (2006) who studied about 750 school principals from South Eastern Pennsylvania who underwent a training at Principal Technology Leadership Academy (PTLA). She zoomed further into fifteen of them for a thorough in-depth interview. Through the interview she was able to collect elements of practices and she even categorized them into three themes/ strategies. After analyzing her findings, the researcher managed to draw up a framework as in Figure 1 below.

As for the methodology, a sample of 106 secondary school principals randomly chosen across two states (Federal Territory \& Selangor) in Malaysia participated in this study. A survey method was employed for the collection of data using the instrument PLICT Questionnaire which was developed by the researcher by assembling the elements of practices discovered by Koslozki through her in-depth interviews. The time of collection of data was sometime in April 2011. As for the internal consistency, it was found that for the modeling strategy comprising 23 items, the Cronbach Alpha was 0.925, for the promoting strategy comprising 26 items, alpha was 0.926 and for the creating opportunity strategy comprising 16 items, the alpha was 0.925 . Collectively the Cronbach Alpha was 0.928 for the whole instrument. This index of reliability ensures that the instrument can be used for collecting relevant data.

\section{The Findings}

The demographic variables indicated that about 53\% principals were males compared to some $47 \%$ females. And about $59 \%$ principals had higher degrees (Masters and $\mathrm{PhD}$ ) as compared to $41 \%$ with first degrees. At least 10 principals from the sample had doctorates. There was also a question on whether there was any training pertaining to ICT skills. About $60 \%$

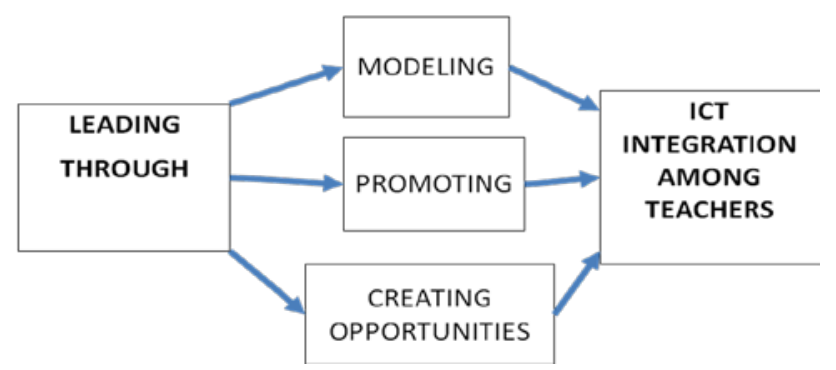

Figure 1.

A Framework based on the findings of Kirsten Koslozki (2006). 
answered yes while another $40 \%$ said no to this item. The findings suggest that the higher the academic qualification, the higher was the mean score of the principals in all three strategies. Additionally, those who said that they had some training also indicated a higher mean in all the three strategies.

As can be seen from Figure 2 below, it is the modeling strategy that shows the highest score $(\mathrm{M}=3.912$; $\mathrm{SD}=0.611)$. The other two strategies, creating opportunity $(\mathrm{M}=3.830$; SD $=0.643)$ and promoting $(\mathrm{M}=3.802$; $\mathrm{SD}=0.573)$ are on the lower end indicating that the principals have less of these skills (such as promoting, communicating, motivating, etc) that are more related and relevant to these two strategies.

Table 1 below shows the top ten activities performed by the principals under the modeling strategy. It is evident that skills like using ICT for data analysis, school management purpose, personal organization, performing teacher evaluations, and accessing important information or taking notes at meetings seem to top the list of activities by the principals in the modeling strategy with scores above 3.92 on a Likert scale of 1 to 5 .

The top ten activities related to the strategy of creating opportunities are listed in the Table 3 below.

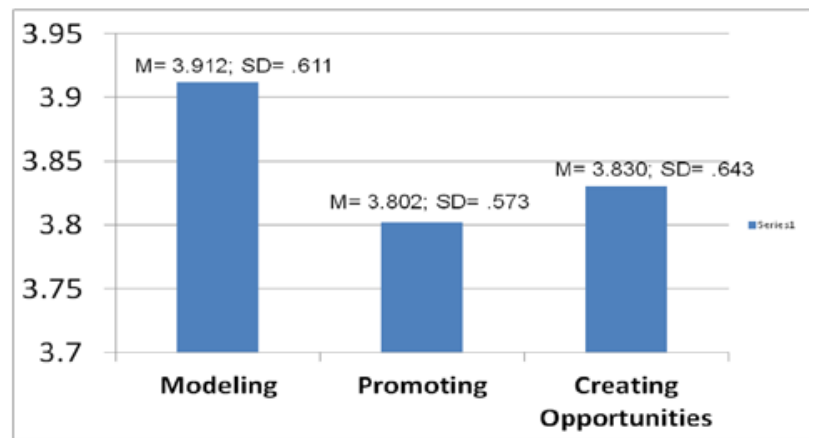

Table 1.

Mean and standard deviation of strategies.

Table 1.

Top 10 activities under the modeling strategy.

\begin{tabular}{|c|c|c|c|}
\hline & $\begin{array}{l}\text { In MODELING the ICT integration, } \\
\text { principals }\end{array}$ & Mean & $\begin{array}{l}\text { Standard } \\
\text { Deviation }\end{array}$ \\
\hline 1 & use ICT for data analysis & 4.21 & .801 \\
\hline 2 & use ICT for school management purposes & 4.20 & .761 \\
\hline 3 & use ICT for my personal organization & 4.02 & .851 \\
\hline 4 & use ICT to perform teacher evaluations & 3.98 & .743 \\
\hline 5 & $\begin{array}{l}\text { use ICT to access important information or } \\
\text { take notes at meetings }\end{array}$ & 3.92 & .765 \\
\hline 6 & $\begin{array}{l}\text { use ICT to communicate information with } \\
\text { teachers }\end{array}$ & 3.90 & .904 \\
\hline 7 & $\begin{array}{l}\text { model the use of information access with } \\
\text { the teachers }\end{array}$ & 3.84 & .806 \\
\hline 8 & $\begin{array}{l}\text { use a variety of media and formats to } \\
\text { communicate, interact and collaborate with } \\
\text { other principals and experts }\end{array}$ & 3.81 & .895 \\
\hline 9 & $\begin{array}{l}\text { model the use of ICT to access, analyze } \\
\text { and interpret student data to focus on } \\
\text { improving student learning }\end{array}$ & 3.80 & .960 \\
\hline 10 & use ICT for budget using Excel & 3.75 & .964 \\
\hline
\end{tabular}

As indicated in Table 2 above, creating opportunities for col-laboration between colleagues with similar goals, supporting teachers in their individual growth plans, increasing meaningful opportunities for teachers to acquire skills on how to integrate ICT, providing adequate access to use ICT for practice and to implement what they have learned in school, involving the whole school community in ICT integration emerged as the top activities of principals in the creating the opportunity strategy.

As shown in Table 3 above, in the promoting strategy, allocating ICT resources to enable teachers to better integrate ICT, overseeing the development of a vision for ICT integration, allocating adequate, timely and high quality support services, changing teachers' old paradigm, and getting additional fund for ICT resources seem to top the list with scores above 3.97 on a Likert scale of 1 to 5 .

As for the demographic differences, beginning with the gender differences, there were no significant differences between male and female principals in all three strategies as shown by the T-test $(p>0.05)$. In terms of the highest qualifications, there was a significant difference $(p<0.05)$ between principals with first degree( bachelor degree) and higher degrees (masters or doctorates). The principals with higher degrees showed higher scores in their mean. Further, those who claimed that they have undergone some ICT training significantly showed higher means in all three strategies than those who didn't go for training.

Generally, the principals use all three strategies even though at varying degrees of strength. It is found that the modeling strategy indicates the highest strength followed by creating opportunities and finally the promoting strategy in leading their teachers' ICT integration.

Table 2.

Top 10 activities of the principals under the creating opportunity strategy.

\begin{tabular}{|c|c|c|c|}
\hline & $\begin{array}{l}\text { In CREATING OPPORTUNITIES for } \\
\text { ICT integration, principals }\end{array}$ & Mean & $\begin{array}{l}\text { Standard } \\
\text { Deviation }\end{array}$ \\
\hline 1 & $\begin{array}{l}\text { create opportunities for collaboration be- } \\
\text { tween colleagues with similar goals }\end{array}$ & 4.72 & 0.901 \\
\hline 2 & $\begin{array}{l}\text { support teachers in their individual growth } \\
\text { plans }\end{array}$ & 4.28 & 0.713 \\
\hline 3 & $\begin{array}{l}\text { increase meaningful opportunities for } \\
\text { teachers to acquire skills on how to inte- } \\
\text { grate ICT }\end{array}$ & 4.04 & 0.721 \\
\hline 4 & $\begin{array}{l}\text { provide adequate access to use ICT for } \\
\text { practice and to implement what they have } \\
\text { learned in school }\end{array}$ & 4.02 & 0.707 \\
\hline 5 & $\begin{array}{l}\text { involve the whole school community in } \\
\text { ICT integration }\end{array}$ & 4.00 & 0.834 \\
\hline 6 & $\begin{array}{l}\text { ensure teachers get sufficient time to prac- } \\
\text { tice ICT integration skills }\end{array}$ & 3.98 & 0.707 \\
\hline 7 & $\begin{array}{l}\text { collaborate in the design, implementation, } \\
\text { and support of the professional develop- } \\
\text { ment for my teachers }\end{array}$ & 3.98 & 0.897 \\
\hline 8 & $\begin{array}{l}\text { provide workshops to interested teachers on } \\
\text { how to integrate ICT }\end{array}$ & 3.91 & 0.929 \\
\hline 9 & $\begin{array}{l}\text { provide ongoing, timely professional de- } \\
\text { velopment that focuses on teaching and } \\
\text { learning using ICT integration }\end{array}$ & 3.89 & 0.814 \\
\hline 10 & $\begin{array}{l}\text { Use trainers to help introduce and demon- } \\
\text { strate ICT integration }\end{array}$ & 3.85 & 0.807 \\
\hline
\end{tabular}


Table 3.

Top 10 activities of the principals under the promoting strategy.

\begin{tabular}{|c|c|c|c|}
\hline & $\begin{array}{l}\text { In PROMOTING ICT integration, } \\
\text { principals }\end{array}$ & $\begin{array}{l}\text { Mea } \\
\mathrm{n}\end{array}$ & $\begin{array}{l}\text { Standard } \\
\text { Deviation }\end{array}$ \\
\hline 1 & $\begin{array}{l}\text { allocate ICT resources to enable teachers } \\
\text { to better integrate ICT }\end{array}$ & 4.05 & .821 \\
\hline 2 & $\begin{array}{l}\text { oversee the development of a vision for } \\
\text { ICT integration by working with staff/ICT } \\
\text { committee }\end{array}$ & 4.03 & .749 \\
\hline 3 & $\begin{array}{l}\text { allocate adequate, timely and high quality } \\
\text { support services for ICT integration }\end{array}$ & 4.01 & .845 \\
\hline 4 & change teachers' old paradigm & 3.99 & .737 \\
\hline 5 & get additional fund for ICT resources & 3.97 & .668 \\
\hline 6 & $\begin{array}{l}\text { provide additional hardware such as inter- } \\
\text { active whiteboard \& LCD projector }\end{array}$ & 3.97 & .845 \\
\hline 7 & $\begin{array}{l}\text { assist teachers in using ICT to access, } \\
\text { analyze and interpret student performance }\end{array}$ & 3.95 & .809 \\
\hline 8 & $\begin{array}{l}\text { obtain additional hardware for ICT integra- } \\
\text { tion purposes }\end{array}$ & 3.94 & .645 \\
\hline 9 & facilitate ICT integration for teachers & 3.94 & .741 \\
\hline 10 & $\begin{array}{l}\text { use technology to change and reinforce } \\
\text { new communication method (e.g. e mail) }\end{array}$ & 3.92 & .880 \\
\hline
\end{tabular}

\section{Discussion and Conclusion}

Though the study finds that it was the modeling strategy that indicated a higher intensity in terms of the mean score, almost all the skills that are listed under this modeling strategy resemble the basic technological skills usually utilized by the principals. For example, using ICT for data analysis, school management purpose, personal organization, and accessing important information or taking notes at meetings recall the basic competencies of the principals in relation to ICT usage. Kozloski (2006) found that many of the principals she interviewed advocate that modeling is one of the best ways to show teachers to follow their lead in technology, though in some cases the teachers do not have the same perspective as the principals do in their use of ICT applications. Hope and Stakenas (1999) too contented that one of the three primary roles for the principal as technology leaders for better ICT integration among their teachers is role modeling. Further, the Office of Educational Technology (2010) describes the following as the main tasks of technology leadership: modeling the use of technology, supporting technology use in the school, engaging in professional development activities that focus on technology and integration of technology in student learning activities, securing resources to support technology use and integration in the school, and advocating for technology use that supports student learning. In fact, creating opportunities and promoting strategies are also equally important as they allow the principals to provide teachers with access to technology resources within the school, have them work with colleagues in technology- supported instructional design projects, give them time and recognition for their participation (UNESCO Bangkok, 2004; 2005). Teachers need to be given time to participate in training activities and they need to be given time to try out what they have learned in the classroom. Hence, the school administrators' lower intensity in these two strategies is an indication that there is a strong need for related training and exposure to these principals in per- forming their role as better technology leaders in their organizations.

Integrating ICT requires teachers to possess the right skills and attitude for doing that (Carlson and Gadio, 2002). And very often, the teachers are found to be relating their performance to the leadership of their schools. When they perceive a good leadership from their principals, they seem to be actively involved in the programmes that are developed by the leadership to enhance their ICT skills. In other words, they try to imitate their role models who can be their own principals (Sathiamoorthy, 2002). If only school leaders realize their role as technology leaders and show better leadership and vision for technology, they can inspire their teachers in the quest for more knowledge and skills and be able to ensure complete and sustained implementation of the vision (Creighton, 2003). At the same time principals can provide the alignment between technology and instructional practices, and some real time collaboration for teachers in the area of technology integration, and just in time professional development (Yee, 2000). And it is highly possible to talk about real technology leadership when these principals show high competency in the leadership and vision dimension (Banoglu, 2011).

The integration of ICT into teaching and learning seems one worthy effort by the Ministry of Education, Malaysia (MOE) in making the integration of ICT a norm in every school if not most schools. Continuous efforts towards that are being taken to enhance teachers' ICT skills in all schools in the Malaysian context. In line with that, it would be fruitful for the Ministry of Education and its training arms if they become more aware of the need to prepare and equip the existing principals to be better technology leaders with strong skills to use strategies such as modelling, creating opportunity and promoting to foster and lead better ICT integration among their teachers.

Many school leaders are uncomfortable providing leadership in technology areas. They may be uncertain about implementing effective technology leadership strategies in ways that will improve learning. They may even believe that their own knowledge of technology is inadequate to make meaningful recommendations. However, among such a group of leaders, this study has brought to the surface that there are principals who claim that they have undergone some training, may be just technological skills training and not technology leadership skills per se, who show that they have an advantage in employing the strategies. Based on the findings of the study, it can be assumed further that by providing the appropriate technology leadership skills to these principals, we could generate a lot more real technology leaders that can easily lead teachers' ICT integration for better student learning.

\section{REFERENCES}

Banoglu, K. (2011). School principals’ technology leadership competency and technology coordinatorship. Educational Sciences: Theory \& Pratice, 11 (1), 208-213.

Brockmeier, L.L., Sermon, J.M., \& Hope, W.C. (2005). Principal's relationship with computer technology. NASSP Bulletin, 89 (643), 45-63.

Carlson, S. and C.T. Gadio. (2002). Teacher professional development in the use of technology. In W.D. Haddad and A. Draxler (Eds), Technologies for education: Potentials, parameters, and prospects. Paris and Washington, DC: UNESCO and the Academy for Educational Development. Retrieved 10 August 2011 from http://portal.unesco.org/ci/en/ev.php-URL_ID=22984\&URL_DO=D 
O_PRINTPAGE\&URL_SECTION=201.html

Creighton, T. (2003). The Principal as Technology Leader. Thousand Oaks, CA: Sage Publications.

Hope, W.C., \& Stakenas, R.G. (1999). Leading the technology revolution: A new challenge to principals. In F.Kochan (Ed.), Southern Regional Conference of Educational Leadership 1999 Yearbook: Leadership for the 21st century (pp. 25-31). Auburn, AL: University of Auburn, Pierce Institute.

International Society for Technology in Education (ISTE). (2002). National educational technology standards for administrators. Retrieved May 20, 2011 from http:// cets.iste.org/tssa/pdf/tssa.pdf.

Kamala, S. (2008). Principal as a Technology Leader in a secondary school in Labu District, Negeri Sembilan. Unpublished Masters in Principalship Project, University of Malaya.

Kozloski, C. K. (2006). Principal Leadership For Technology Integration: A Study of Principal Technology Leadership. PhD Thesis, Drexel University.

MacNeil, A. J. \& Delafield, D. P. (1998). Principal leadership for successful school technology implementation. Technology and Teacher Education Annual, 296-300.

Nordin, \& Norazah (2010). A Quantitative Analysis of Malaysian Secondary School Technology Leadership, Management Science and Engineering, April 1, 2010.

Office of Educational Technology (2010, pp. 10-12), Transforming American Education: Learning Powered by Technology: National Education Technology Plan 2010, Executive Summary,

http://www.ed.gov/technology/netp-2010. Retrieved on 3 September 2012

Ritchie, D. (1996). The administrative role in the integration of technology. NASSP Bulletin, 80(582), 42-52.

Rossafri Mohamad, and Balakrishnan Munindy. (2007). Translating technology leadership to create excellent instructional leadership. Educational Leadership and Management Journal, 17(2), 91-103.

Sathiamoorthy, K. (2002). A study of managing ability to integrate computer into teaching-learning among smart school teachers. Educational Leadership and Management Journal, 12(2), 126-151.

Sathiamoorthy. K., Leong, M. W. \& M. Jamil Saleh (2011). Principal Technology Leadership and Teachers' ICT Applications in two different school settings in Malaysia, Paper submitted for presentation at the International Conference On "Aplication of ICT in economy and education “ (icaictee 2011), December 2 - 3, 2011, UNWE, Sofia, Bulgaria

Schiller, J. (2000). Implementation of computing in schools by primary principals: A longitudinal perspective. Paper presented at Australian Association for Research in Education (AARA), Sydney, Australia. Retrieved on May 20, 2011 from http://www.aare.edu.au/index.htm.

Stegall, P. (1998). The principal-key to technology implementation. Paper presented at the annual meeting of the National Catholic Education Association, Los Angeles, CA.

Traci, R. \& Chan, C. T. (2007). Technology Leadership: Aspiring Administartors' Perseption. Journal for The Integration of Technology In Education, 6(3), 123-139.

UNESCO Bangkok. (2004). Integrating ICTs into education: Lessons learned. Retrieved from

http://www.unescobkk.org/index. php?id=1793

UNESCO Bangkok. (2005). Regional guideline on teacher development for pedagogy-technology integration. Retrieved from http://www.unescobkk.org/fileadmin/user_upload/ict/e-books/Draft_ Regional_Guidelines/Regional_guidelines.pdf

Wilmore, D. \& Betz, M. (2000). Information technology and schools: The principal's role. Educational Technology \& Society, 3(4). Retrieved May 29, 2011 from http://ifets.ieee.org/periodical/vol_4_2000/V_4_2000.html

Yee, D.L. (2000). Images of school principals' information and communications technology leadership. Journal of Information Technology for Teacher education, 9(3), 287-302. 